\title{
Morpho-physiological and mineral nutrient characterization of 45 collected Purslane (Portulaca oleracea L.) accessions
}

\author{
Amirul Alam ( ${ }^{1 *}$; Abdul Shukor Juraimi ( $\left.{ }^{1}\right)$; Mohd Rafii Yusop ('); Azizah Abdul Hamid (2); Abdul Hakim ( $\left.{ }^{3}\right)$ \\ (1) University Putra Malaysia, Faculty of Agriculture, Dept. of Crop Science, UPM Serdang, Selangor, DE 43400, Malaysia. \\ (2) University Putra Malaysia, Faculty of Food Science and Technology, UPM Serdang, Selangor, DE 43400, Malaysia. \\ (3) University Putra Malaysia, Institute of Tropical Agriculture, UPM Serdang, Selangor, DE 43400, Malaysia. \\ ${ }^{*}$ ) Corresponding author: amirul81@gmail.com
}

Received: ago 9, 2014; Accepted: ago 24, 2014

\begin{abstract}
This study was carried out to determine, evaluation and characterization of the morphological, physiological as well as mineral nutrient vitiations among all forty five purslane accessions collected from different locations of West Peninsular, Malaysia. Significant differences $(p<0.05)$ were observed for all those traits measured regarding morphological, physiological and mineral composition. Morphological traits viz. plant height varied between 20.06-40.8 cm; number of main branch, 1.4-4.4; number of nodes, 8.4-31; internode distance, 2.1-3.43 cm; stem diameter, 2.12-3.8 mm; number of leaves, 97-1019; leaf area, 1.03-2.21 cm², number of flowers, 14-826.8; root length, 5.09-11.7 cm; fresh weight, 40-280 g; and dry weight varied between 2.71-29.16 g. Among physiological traits, total chlorophyll content varied between 26.2-39.52 (SPAD value), net photosynthesis, 20.8-28.73 $\mathrm{mol} \mathrm{CO} / \mathrm{m}_{2}^{2} / \mathrm{sec}$; stomatal conductance, $0.02-0.28 \mathrm{~cm} / \mathrm{sec}$; transpiration rate, $0.46-2.48 \mathrm{~mol} / \mathrm{m}^{2} / \mathrm{sec}$; and water vapor deficit varied between $0.51-2.65 \mathrm{~mol} \mathrm{H} \mathrm{H}_{2} \mathrm{O} / \mathrm{m}^{2} / \mathrm{sec}$. Analysis of mineral macro and micro nutrient compositions showed that all accessions contained appreciable amount of essential nutrients. Among the macro nutrient elements; N, P, K, Ca and Mg contents ranged respectively between 31.2-100, 2.51-8.2, 78.4-276, 9.1-62.2 and 8.7-32.55 ppm. Whereas micro nutrient elements; Zn, Fe and Mn ranged respectively between 0.31-1.09; 1.01-13.09 and 0.06-1.32 ppm. This great variability among the purslane accessions may contribute enhancing the genetic improvement of the species for desired traits.
\end{abstract}

Key words: Purslane, total chlorophyll, photosynthesis, stomatal conductance, transpiration, mineral composition.

\section{Caracterização morfofisiológica e nutricional de 45 acessos de beldroegas (Portulaca oleracea L.)}

\section{Resumo}

Este estudo foi realizado para determinar aspectos morfológicos, fisiológicos e nutricionais (teor vitamínico) de 45 acessos de beldroegas coletadas em diferentes locais da Península Ocidental da Malásia. Observaram-se diferenças significativas $(p<0,05)$ para todos os caracteres avaliados, considerando-se características morfológicas, fisiológicas e de composição. Para as características morfológicas observaram-se as seguintes variações: altura das plantas (20,06-40,8 cm); número de ramos principais (1,4-4,4); número de nós (8,4-31); distância entre internódio (2,1-3,43 cm); diâmetro do caule (2,12-3,8 mm); número de folhas (97-1.019); área foliar (1,03-2,21 cm²); número de flores (14-826,8); comprimento da raiz $(5,09-11,7 \mathrm{~cm})$; peso fresco (40-280 g); e massa seca (2,71-29,16 g). Dentre as características fisiológicas verificaram-se as seguintes variações: teor de clorofila total (26,2-39,52; valor SPAD); fotossíntese líquida (20,8-28,73 mol CO2/m²/s); condutância estomática $(0,02-0,28 \mathrm{~cm} / \mathrm{s})$; taxa de transpiração $\left(0,46-2,48 \mathrm{~mol} / \mathrm{m}^{2} / \mathrm{s}\right)$; e déficit de vapor d’água $\left(0,51-2,65 \mathrm{~mol} \mathrm{H} 2 \mathrm{O} / \mathrm{m}^{2} / \mathrm{s}\right)$. As análises de macro e micronutrientes indicaram que todos os acessos apresentam quantidade significativa de nutrientes essenciais. Entre os macronutrientes: N, P, K, Ca e Mg variaram, respectivamente, entre 31,2-100; 2,51-8,2; 78,4-276; 9,1-62,2; e 8,7-32,55 ppm. Enquanto os micronutrientes; Zn, Fe e Mn variaram, respectivamente, entre 0,31-1,09; 1,01-13,09; e 0,06-1,32 ppm. Essa grande variabilidade entre os acessos de beldroegas pode contribuir para o melhoramento genético dessa espécie.

Palavras-chave: clorofila total, fotossíntese, condutância estomática, transpiração, composição mineral. 


\section{INTRODUCTION}

The purslane (Portulaca oleracea L.,) is listed in the World Health Organization (WHO) as one of the most used medicinal plants and it has been given the term 'Global Panacea' (Samy et al., 2004). The genus Portulaca comprising about 70 species is characterized by conspicuously fleshy sessile leaves (Jonas et al., 1972). Many varieties of purslane under many names grow in a wide range of climates and regions (Alam et al., 2014a).

It can be found in Europe, Africa, North America, Australia and Asia (Liu et al., 2000; Rashed et al., 2003). Purslane has been ranked the eight most common plants in the world and is widespread as a weed, fast growing, self-compatible and have amazing ability to produce seeds even on death's doorstep (Liu et al., 2000). The common purslane begins flowering 20 to 30 days after emergence and produces a single, five-petalled little yellow flower at the ends of its stems but the ornamental ones produces flowers of different colors. The blossom of common ones remains open only briefly, but the resultant seedpod is filled with tiny seeds. The plants produce 4 to 15 seeds/ capsule depending on environmental conditions, with an average of 9.4 seeds per capsule (Galinato et al., 1999). Seed production of this weed ranges from 126 to 16,300 seeds/ plant with an average of 6,940 seeds/plant (Galinato et al., 1999). Freshly collected seeds have no dormancy and germinate immediately after maturity (Balyan and Bhan, 1986). However, seeds of purslane have the ability to remain viable in soil for up to 40 years (Helen and eHow Contributor, 2004). Its shiny, fleshy leaves have red margins, and are teardrop or wedge-shaped. Leaves are between $1 / 4$ inch and 2 inch long, and 1/6-1/2 inch wide. Leaves are attached to stems without a stalk, and at the lower ends of stems, leaves are arranged alternately, but are produced in clusters at stem tips. Stems are smooth, branched and often pinkish or reddish. Stems radiate up to 20 inches outward from a central root. Purslane has better nutritional quality than the major cultivated vegetables, with higher $\beta$-carotene, ascorbic acid, and $\alpha$-linolenic acid, an essential fatty acid content (Liu et al., 2000). Additionally, because of its high nutritive and antioxidant properties purslane has been described as a "power food" (Alam et al., 2014b; Simopoulos et al., 1995). The common purslane which is largely consumed in the Mediterranean basin is the richest source of $\alpha$-linolenic acid (ALA) among green leafy vegetables and a rich source of antioxidants (Alam et al., 2014c; Simopoulos et al., 1992). Variation in harvesting times, environmental conditions and different varieties can contribute to purslane nutritional composition and benefits (Liu et al., 2000), and possibly to its biological activity.

Purslane can grow readily in any soils whether arid or saline. Due to its salinity tolerance purslane is listed as halophyte in the Haloph database (Alam et al., 2014d) especially to the chlorine salinity. Yazici et al. (2007) suggested purslane as a promising candidate for use in drainage water reuse system, not only its survivability and water use, but also its usefulness as a vegetable and oil seed crop. Grieve and Suarez (1997) showed that purslane reallocates resources and energy to counteract osmotic and/or ionic effects of salt stress, which enables it to resist salinity and thus to complete its life cycle and produce seeds. In Malaysia purslane is still being treated only as a weed and its cultivation as a food crop and the effects of cultural conditions on its nutritional value is known very little. Estimation of the phylogenetic relationship and knowing the genetic diversity between genotypes in germplasm of any species is essential as it provides useful traits for further genetic development and increase selection efficiency. Genetic diversity in plant varieties can be estimated by observing the phenotypes of the plants and measuring the morphological characters which in turn lay foundation for breeding programs. In the present study, morphological, physiological and nutritional traits of 45 purslane accessions collected from different location of West Peninsular Malaysia were investigated for their genetic diversity information.

\section{MATERIAL AND METHODS}

\section{Experimental site and soil}

A pot $(24 \times 22 \mathrm{~cm})$ experiment was conducted during January 2012 to April 2012 in the glasshouse of Field-2 at the Faculty of Agriculture, University Putra Malaysia ( $3^{\circ} 00^{\prime} 21.34^{\prime \prime} \mathrm{N}, 101^{\circ} 42^{\prime} 15.06^{\prime \prime} \mathrm{E}, 37 \mathrm{~m}$ elevation). The plastic pots were filled with soil $(39.51 \%$ sand, $9.03 \%$ silt and $51.35 \%$ clay) of $\mathrm{pH} 4.8$ with $2.6 \%$ organic carbon, $1.24 \mathrm{~g} \mathrm{cc}^{-1}$ bulk density and CEC of $7.07 \mathrm{meq} 100 \mathrm{~g}^{-1}$ soil. Soil nutrient status was $0.16 \%$ total N, $5.65 \mathrm{ppm}$ available P, 15.3 ppm available K, 3295 ppm Ca and 321 ppm Mg. At field capacity, soil water retention was $31.18 \%$ (wet basis) and $45.31 \%$ (dry basis). The experimental soil belongs to the Serdang series.

\section{Plant materials and experimental design}

Ten-day-old young seedlings/cuttings (as ornamental purslane does not produce seed) of 45 purslane accessions were collected from different locations of West Peninsular Malaysia and were transplanted into the pots. The pots were arranged in RCBD randomized complete block design (RCBD) with three replications. Brief descriptions of the collected purslane accessions and locations have been shown in table 1 and figure 1. 


\section{Plants rearing, data collection and analysis}

Four to five seedlings were transplanted in each pot and were surface irrigated every alternate day throughout the growing period using tape water. All types of weeds or any other plant seedlings were uprooted just after emergence and regular observation continued up to harvesting. Purslane blooms everyday so total numbers of flowers were counted daily and recorded. Regarding morphological attributes plant height $(\mathrm{cm})$, number of nodes, internode distance $(\mathrm{cm})$,

Table 1. Brief description of collected 45 purslane samples with specific locations of West Peninsular Malaysia

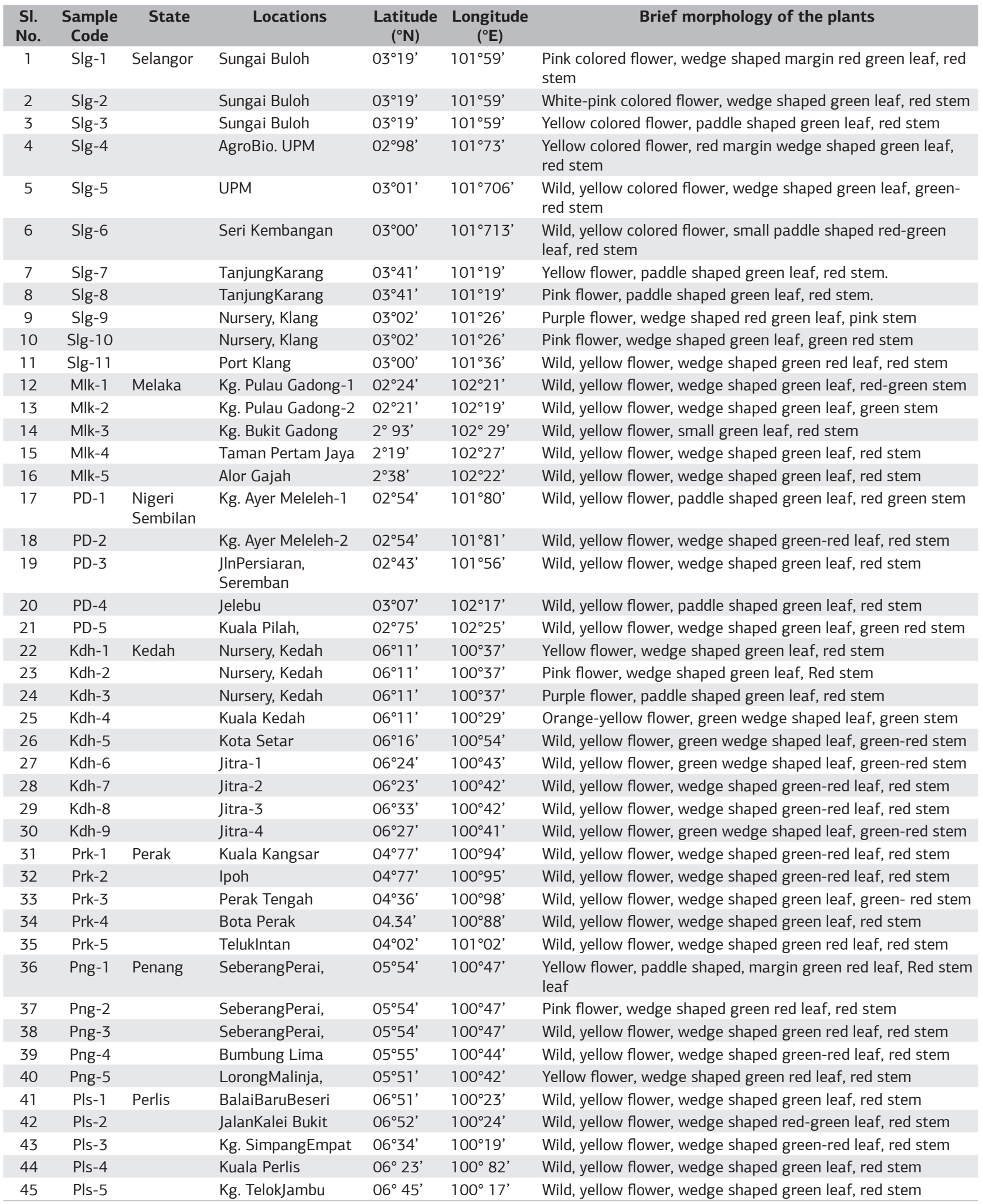



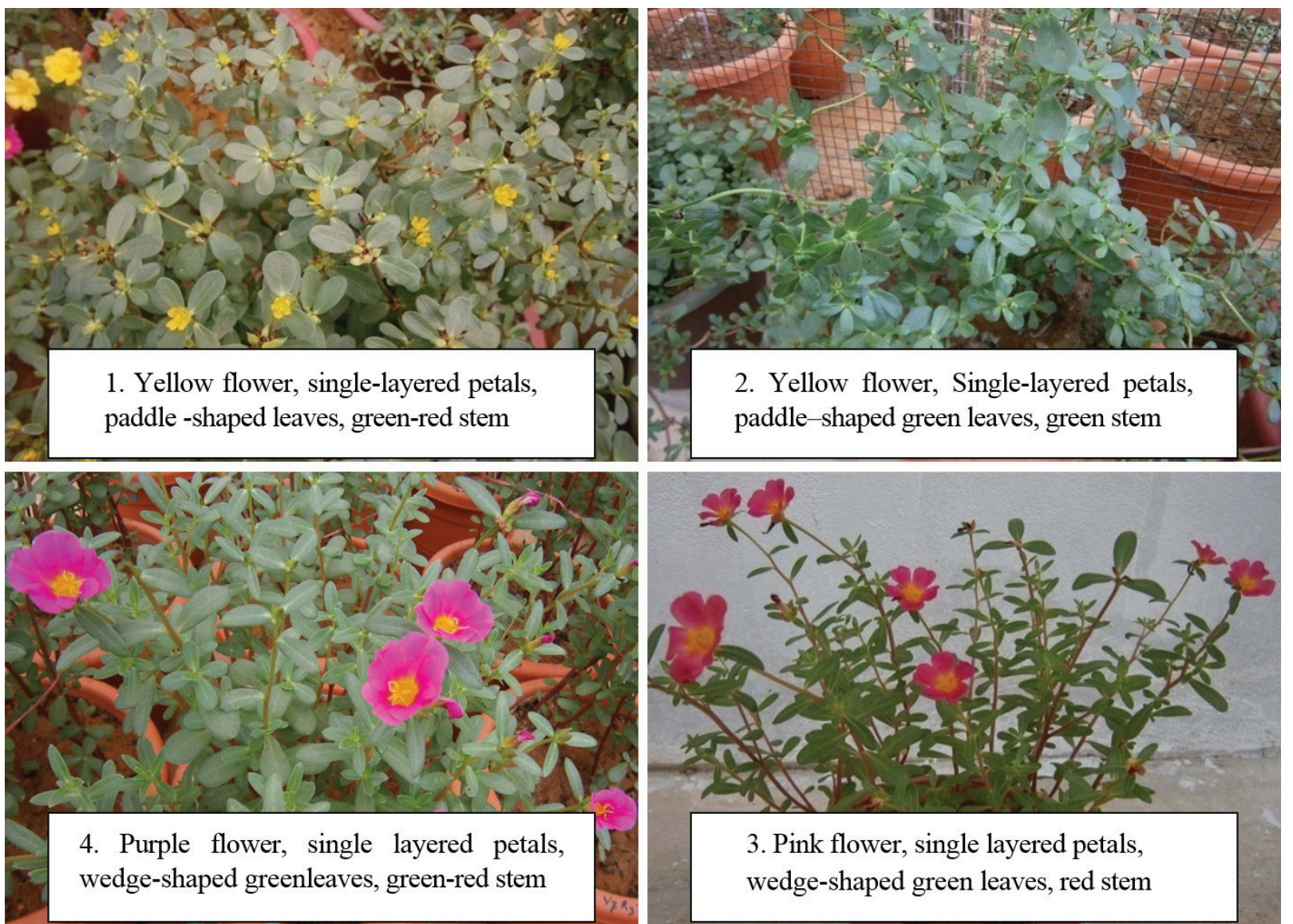

4. Purple flower, single layered petals,

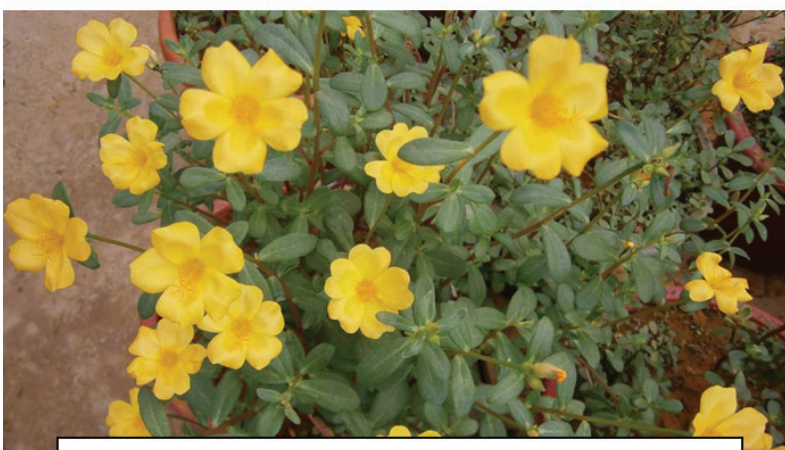

3. Pink flower, single layered petals, wedge-shaped green leaves, red stem

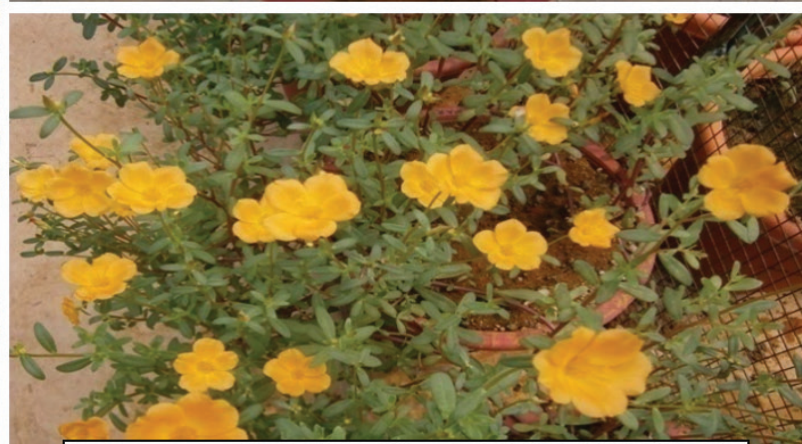

5. Yellow flower, single-layered petals, wedge -shaped green leaves, green-red stem

6. Orange-Yellow flower, single-layered petals, wedge-shaped green leaves, red stem

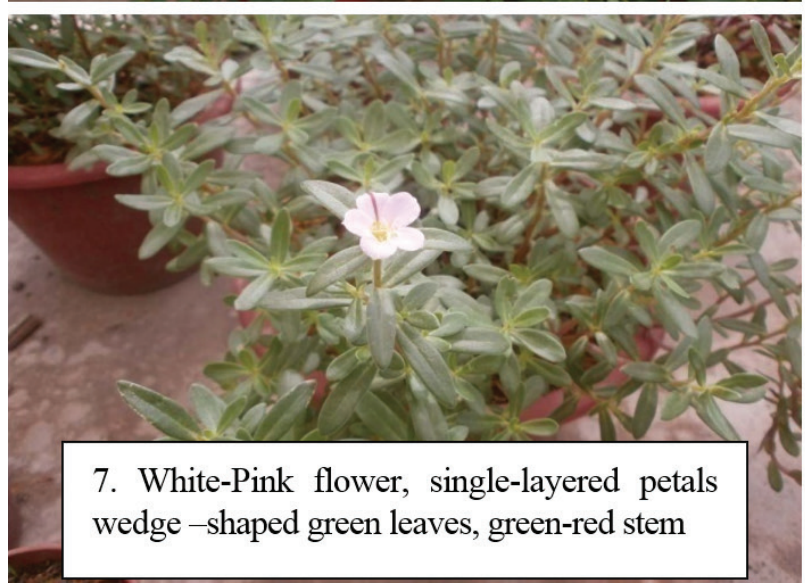

Figure 1. Different cultivars of Purslane (Portulaca oleracea L.) with morphological descriptions available in Malaysia. 
number of main branch, stem diameter $(\mathrm{mm})$, number of leaves, leaf area $\left(\mathrm{cm}^{2}\right)$, root length $(\mathrm{cm})$, fresh weight $(\mathrm{g})$ and dry weight $(\mathrm{g})$ of the plants were determined. Average leaf area was measured using leaf area meter (LI-Cor, Model LI-3100 Area Meter, LI-COR Inc. Lincoln, Nebraska, USA).

Regarding physiological data; the net photosynthesis rate $\left(\mu \mathrm{mol} \mathrm{CO} / \mathrm{Cm}^{2} / \mathrm{sec}\right)$, Stomatal conductance $(\mathrm{cm} / \mathrm{sec})$, transpiration rate $\left(\mathrm{mol} / \mathrm{m}^{2} / \mathrm{sec}\right)$ and water vapor deficit ( $\mathrm{mol} \mathrm{H} \mathrm{H}_{2} \mathrm{O} / \mathrm{m}^{2} / \mathrm{sec}$ ) were determined by LI-COR, LI 6400 Portable Photosynthesis System; LI-Cor, Inc., Lincoln, NE, USA. Relative chlorophyll content or greenness of leaves was measured at 60 days after transplanting $\left(\mathrm{SPAD}_{60}\right)$ using portable chlorophyll meter or SPAD meter (MINOLTA ${ }^{\mathrm{TM}}$ SPAD-502, Minolta Camera Co., Osaka, Japan). Five leaf SPAD readings were taken and then averaged to have mean SPAD reading foreach replicate. The SPAD meter (Minolta) works using light sources and detects the light transmitted by a plant leaf at two wavelengths (at red and infrared region of the spectrum) (Biljana and Aca, 2009)

Purslane plants are very succulent and contain mucilaginous substances and water contents is about $90 \%$ or more so for initial drying just after harvesting the fresh samples were stored in a cool dry place for 3 days then kept in oven at $40{ }^{\circ} \mathrm{C}$ temperature for 3 days (to dry and prevent from sudden burning injury) and then transferred to $70{ }^{\circ} \mathrm{C}$ for another 72 hours. The oven-dried purslane samples were ground and stored in plastic bottles. For the measurement of macro minerals ( $\mathrm{N}, \mathrm{P}, \mathrm{K}, \mathrm{Na}, \mathrm{Ca}$ and $\mathrm{Mg}$ ) and micro ( $\mathrm{Fe}, \mathrm{Mn}$ and $\mathrm{Zn}$ ) minerals contents were analyzed using the digestion method (Ma and Zua, 1942) and determined using an Atomic Absorption Spectrophotometer (AAS; Perkin Elmer, 5100, USA). Among the macro minerals N (Nitrogen) was determined using micro Kjeldahl method (Hawk et al., 1948) and P (Phosphorus) was determined calorimetrically following the method of Yoshida et al. (1965).

\section{Statistical analysis}

All recorded data were subjected to analysis of variance using the SAS statistical software package version 9.3 (SAS INSTITUTE, 2013). Significant differences among means were calculated using Fisher's protected LSD (Least Significant Difference) test at 5\% level of significance.

\section{RESULTS}

\section{Morphological traits analysis}

The analysis of variance of 45 purslane accessions regarding all the morphological traits revealed significant variation among all the accessions and characteristics measured
(Table 2). The highest plant height, highest numbers of main branches, number of nodes, internode distance, stem diameter, number of leaves, leaf area, number of flowers, root length, fresh weight and dry weight $(40.8 \mathrm{~cm}, 4.4$, $31,3.43 \mathrm{~cm}, 3.8 \mathrm{~mm}, 1019.2,2.21 \mathrm{~cm}^{2}, 826.8,11.7 \mathrm{~cm}$, $280 \mathrm{~g}$ and $29.16 \mathrm{~g}$ ) was found in accession V12, V25, V4, V12, V2, V6, V11, V15, V34, V6 and V6 respectively where the lowest plant height, highest number of main branch, number of nodes, internode distance, stem diameter, number of leaves, leaf area, number of flowers, root length, fresh weight and dry weight $(20.06 \mathrm{~cm}, 1.4,8.4,2.1 \mathrm{~cm}$, $2.12 \mathrm{~mm}, 97,1.03 \mathrm{~cm}^{2}, 14,5.09 \mathrm{~cm}, 40 \mathrm{~g}$ and $2.71 \mathrm{~g}$ ) was found in accessions V22, V21, V36, V11, V15, V9, V3, V4, V12, V11 and V11 respectively. Results of Pearson's correlation coefficient analysis show positive, negative significant relation and also non-significant relation among the evaluated morphological characters. Pearson's correlation coefficient analysis of the morphological characters is presented in table 3 .

\section{Physiological analysis}

The analyzed data obtained from 45 purslane accessions showed significant differences among all the physiological characteristics regarding total chlorophyll content (SPAD value), net photosynthetic rate ( $\left.\mu \mathrm{mol} \mathrm{CO}_{2 /} \mathrm{m}^{2} / \mathrm{sec}\right)$, stomatal conductance $(\mathrm{cm} / \mathrm{sec})$, transpiration rate $\left(\mathrm{mol} / \mathrm{m}^{2} / \mathrm{sec}\right)$ and water vapor deficit $\left(\mathrm{mol} \mathrm{H}_{2} \mathrm{O} / \mathrm{m}^{2} / \mathrm{sec}\right)$ (Table 4$)$. According to the physiological analysis results the highest amount of total chlorophyll (39.52, SPAD value) was produced by the accessions V29 and the lowest (26.2, SPAD value) chlorophyll was produced by accessions V19 while the highest net photosynthesis rate $\left(24.3 \mu \mathrm{mol} \mathrm{CO} \mathrm{CO}_{2 /} / \mathrm{sec}\right)$ was found in the accession V44 and the lowest $\left(20.8 \mu \mathrm{mol} \mathrm{CO} \mathrm{CO}_{21}\right.$ $\mathrm{m}^{2} / \mathrm{sec}$ ) was found in accession V1. The highest stomatal conductance $(0.28 \mathrm{~cm} / \mathrm{sec})$ was recorded in accession V10 and the lowest $(0.02 \mathrm{~cm} / \mathrm{sec})$ was recorded in accession V14 while the highest transpiration rate $\left(2.86 \mathrm{~mol} / \mathrm{m}^{2} / \mathrm{sec}\right)$ was found in accession V10 and the lowest $\left(0.46 \mathrm{~mol} / \mathrm{m}^{2} / \mathrm{sec}\right)$ was found in accession V1 which is positively proportional with stomatal conductance. On the other hand the highest water vapor deficit $\left(1.84 \mathrm{~mol} \mathrm{H}_{2} \mathrm{O} / \mathrm{m}^{2} / \mathrm{sec}\right)$ was found in accession $\mathrm{V} 1$ where the lowest $\left(0.51 \mathrm{~mol} \mathrm{H} \mathrm{H}_{2} \mathrm{O} / \mathrm{m}^{2} / \mathrm{sec}\right)$ was seen in accession V31. The positive, negative and non-significant correlation obtained from Pearson's correlation coefficient analysis of physiological traits is also presented in table 5 .

\section{Mineral nutrient analysis}

Results from statistical analyses of major macro minerals $(\mathrm{N}, \mathrm{P}, \mathrm{K}, \mathrm{Na}, \mathrm{Ca}$ and $\mathrm{Mg}$ ) and micro minerals ( $\mathrm{Zn}, \mathrm{Fe}$ and $\mathrm{Mn})$ indicate the presence of significant $(\mathrm{p}<0.05)$ variation in all traits evaluated. Elemental composition of the dry 
samples, reported on dry weight basis, is given in table 6. $\mathrm{Na}, \mathrm{Ca}$, and $\mathrm{Mg}(31.2,2.51,74.8,1.04,9.1$ and 8.7) ppm The highest concentration of macro minerals $\mathrm{N}, \mathrm{P}, \mathrm{K}, \mathrm{Na}$, $\mathrm{Ca}$, and $\mathrm{Mg}(100,8.2,276,117.9,62.2$ and32.55) ppm was observed in accessions V7, V15, V7, V4, V15 and V14 was observed in accessions V36, V35, V14, V24, V4 and V44 respectively (Table 6). On the other hand among the respectively. While minimum concentration of $\mathrm{N}, \mathrm{P}, \mathrm{K}$, maximum concentration of micro mineral $\mathrm{Zn}, \mathrm{Fe}$ and $\mathrm{Mn}$ $(1.09,13.78$ and 1.32) ppm was observed in accessions V20,

Table 2. Descriptive statistics of the evaluated morphological traits

\begin{tabular}{|c|c|c|c|c|c|c|c|c|c|c|c|}
\hline Acc. & $\begin{array}{l}\text { Plant } \\
\text { height } \\
(\mathrm{cm})\end{array}$ & $\begin{array}{l}\text { Main } \\
\text { Branch }\end{array}$ & $\begin{array}{l}\text { Number } \\
\text { of nodes }\end{array}$ & $\begin{array}{l}\text { Internode } \\
\text { distance } \\
\text { (cm) }\end{array}$ & $\begin{array}{c}\text { Stem } \\
\text { diameter } \\
(\mathrm{mm})\end{array}$ & $\begin{array}{l}\text { Number } \\
\text { of leaves }\end{array}$ & $\begin{array}{l}\text { Leaf } \\
\text { area } \\
\left(\mathrm{cm}^{2}\right)\end{array}$ & $\begin{array}{c}\text { Number } \\
\text { of } \\
\text { flowers }\end{array}$ & $\begin{array}{l}\text { Root } \\
\text { length } \\
(\mathrm{cm})\end{array}$ & $\begin{array}{l}\text { FW } \\
\text { (g) }\end{array}$ & $\begin{array}{l}\text { DW } \\
(\mathrm{g})\end{array}$ \\
\hline 1 & 37.6 & 2.6 & 23.4 & 2.3 & 3.78 & 146.6 & 2.12 & 134.6 & 7.32 & 230 & 13.69 \\
\hline 2 & 36.8 & 3.2 & 24 & 2.5 & 3.8 & 400.4 & 1.57 & 122.2 & 7.9 & 102 & 7.32 \\
\hline 3 & 23.9 & 2.8 & 12.8 & 2.57 & 2.63 & 197.4 & 1.03 & 175.6 & 6.53 & 69 & 3.08 \\
\hline 4 & 38.2 & 3.8 & 31 & 2.89 & 2.96 & 455.6 & 1.95 & 14 & 6 & 250 & 13.3 \\
\hline 5 & 23.83 & 2.9 & 18.53 & 2.23 & 2.77 & 422.33 & 1.67 & 129.7 & 6.07 & 150 & 10 \\
\hline 6 & 29.4 & 4.4 & 15 & 2.68 & 2.84 & 1019.2 & 1.11 & 765.8 & 7 & 280 & 29.16 \\
\hline 7 & 26.8 & 2.4 & 11 & 2.8 & 2.23 & 367.6 & 1.31 & 234.8 & 7.9 & 100 & 9.45 \\
\hline 8 & 24.2 & 1.9 & 10.5 & 2.75 & 2.38 & 380.4 & 1.18 & 278.7 & 7.1 & 70 & 6.52 \\
\hline 9 & 28.6 & 1.8 & 11.6 & 2.8 & 2.88 & 97 & 1.71 & 94.8 & 7.18 & 50 & 3.25 \\
\hline 10 & 26 & 3.2 & 13.6 & 2.9 & 2.93 & 218 & 1.07 & 179.2 & 7.24 & 60 & 3.16 \\
\hline 11 & 23 & 1.6 & 9.6 & 2.1 & 2.73 & 415 & 2.21 & 409.8 & 7.4 & 40 & 2.71 \\
\hline 12 & 40.8 & 3.4 & 14.6 & 3.43 & 3.1 & 249 & 1.79 & 191.8 & 5.9 & 220 & 15.34 \\
\hline 13 & 29 & 3.8 & 15.2 & 2.7 & 2.77 & 663 & 1.17 & 615 & 9.1 & 130 & 9.21 \\
\hline 14 & 34.4 & 4.1 & 18.6 & 2.73 & 3.13 & 458.4 & 1.97 & 181.4 & 6.6 & 190 & 10.68 \\
\hline 15 & 25.2 & 2.4 & 12 & 2.53 & 2.12 & 903.6 & 1.13 & 826.8 & 10.6 & 129 & 9.1 \\
\hline 16 & 23.4 & 1.8 & 10.8 & 2.38 & 2.89 & 435 & 1.04 & 441.8 & 9.9 & 75 & 7.66 \\
\hline 17 & 40.2 & 3.8 & 19.6 & 3.33 & 2.98 & 330.2 & 1.56 & 185.6 & 8.5 & 175 & 9.8 \\
\hline 18 & 33.6 & 2.6 & 18.2 & 2.77 & 2.83 & 393.33 & 1.66 & 209 & 8.6 & 260 & 15.88 \\
\hline 19 & 28 & 2.2 & 11 & 2.66 & 2.93 & 309.4 & 1.23 & 298.8 & 8.8 & 160 & 12.02 \\
\hline 20 & 30.4 & 2.2 & 12.2 & 2.47 & 2.23 & 319.2 & 1.77 & 290.4 & 10.9 & 120 & 8.42 \\
\hline 21 & 32.5 & 1.4 & 11.2 & 3.1 & 2.98 & 298.6 & 1.91 & 324.4 & 9.7 & 130 & 9.57 \\
\hline 22 & 20.6 & 2.8 & 16.8 & 2.57 & 2.88 & 433.8 & 1.5 & 395.8 & 10.6 & 200 & 12.2 \\
\hline 23 & 27 & 3.2 & 15 & 2.98 & 2.72 & 579.4 & 1.23 & 261.3 & 10.5 & 80 & 3.37 \\
\hline 24 & 28.4 & 2.8 & 11.8 & 3.14 & 2.88 & 750.8 & 1.67 & 533.8 & 8.7 & 50 & 3.66 \\
\hline 25 & 26.2 & 4.4 & 11.6 & 2.53 & 2.92 & 250.4 & 1.13 & 385.8 & 8.92 & 130 & 10.63 \\
\hline 26 & 37.4 & 3.2 & 20.8 & 3.21 & 3.04 & 405.2 & 1.21 & 210.4 & 6.6 & 190 & 16.05 \\
\hline 27 & 27.6 & 1.8 & 11.6 & 2.56 & 2.61 & 612.4 & 1.63 & 551.2 & 6.5 & 178 & 9.81 \\
\hline 28 & 27.6 & 2.8 & 15.4 & 2.7 & 2.71 & 548.4 & 1.71 & 493 & 9.74 & 118 & 6.57 \\
\hline 29 & 30.6 & 3.8 & 11.83 & 3.03 & 3.1 & 768.2 & 1.14 & 691.83 & 8.58 & 150 & 14.52 \\
\hline 30 & 35.2 & 3.2 & 14.2 & 3.24 & 2.94 & 588.4 & 1.47 & 587.83 & 7.84 & 110 & 10.47 \\
\hline 31 & 31.4 & 3.2 & 13.4 & 3.3 & 3.02 & 622 & 1.42 & 618.4 & 9.32 & 140 & 11.92 \\
\hline 32 & 29.6 & 3.4 & 13.6 & 3.2 & 2.91 & 767.6 & 1.47 & 504 & 9.18 & 80 & 8.2 \\
\hline 33 & 38.6 & 3.4 & 17.8 & 2.67 & 2.89 & 155.4 & 1.88 & 290.6 & 7.9 & 240 & 20.37 \\
\hline 34 & 37.4 & 3.2 & 15.4 & 2.6 & 2.68 & 340 & 1.24 & 224.2 & 11.7 & 140 & 12.95 \\
\hline 35 & 29.2 & 2.8 & 15.4 & 3.1 & 2.93 & 671.8 & 1.13 & 430.4 & 9.2 & 60 & 5.6 \\
\hline 36 & 27.4 & 4 & 8.4 & 2.9 & 2.99 & 238.93 & 1.63 & 312 & 9.66 & 145 & 6.89 \\
\hline 37 & 33.2 & 3.4 & 15 & 2.22 & 2.92 & 552.8 & 1.71 & 307.4 & 10.86 & 135 & 7.54 \\
\hline 38 & 30 & 4 & 11 & 2.96 & 2.81 & 370 & 1.66 & 479.4 & 9.3 & 180 & 15.02 \\
\hline 39 & 33.2 & 3.2 & 10.8 & 3.1 & 2.95 & 192 & 1.97 & 89.4 & 8.6 & 272 & 26.17 \\
\hline 40 & 29.3 & 3.4 & 12.8 & 2.8 & 2.86 & 412.6 & 1.05 & 326.6 & 9 & 60 & 6.45 \\
\hline 41 & 31.4 & 3.9 & 17.8 & 3 & 2.85 & 608 & 1.25 & 415 & 9.4 & 110 & 9.37 \\
\hline 42 & 24.2 & 3.4 & 12.73 & 3.22 & 2.94 & 455 & 1.47 & 393.6 & 8.5 & 140 & 12.37 \\
\hline 43 & 33.8 & 3.8 & 12 & 3.2 & 3.05 & 338 & 1.8 & 196.53 & 9.3 & 160 & 14.76 \\
\hline 44 & 28.6 & 2 & 10.4 & 2.9 & 2.52 & 190.4 & 2.02 & 77.6 & 8.5 & 70 & 3.69 \\
\hline 45 & 35.2 & 3.2 & 14.2 & 3.24 & 2.94 & 588.4 & 1.47 & 587.83 & 7.84 & 110 & 10.47 \\
\hline Mean & 30.42 & 3.03 & 14.54 & 2.82 & 2.86 & 442.64 & 1.15 & 343.74 & 8.49 & 138.62 & 10.41 \\
\hline Max. & 40.8 & 4.4 & 31 & 3.43 & 3.8 & 1019.2 & 2.21 & 826.8 & 11.7 & 280 & 29.16 \\
\hline Min. & 20.06 & 1.4 & 8.4 & 2.1 & 2.12 & 97 & 1.03 & 14 & 5.9 & 40 & 2.71 \\
\hline LSD & 5.03 & 0.61 & 3.58 & 0.44 & 0.57 & 0.46 & 0.45 & 6.42 & 1.13 & 25.3 & 0.82 \\
\hline CV & 10.23 & 12.26 & 15.19 & 9.81 & 12.32 & 14.79 & 18.55 & 15.12 & 8.25 & 11.23 & 4.88 \\
\hline
\end{tabular}


Table 3. Pearson's correlation coefficient among different morphological traits of purslane

\begin{tabular}{|c|c|c|c|c|c|c|c|c|c|c|c|}
\hline Factor & PH & MB & ND & ID & SD & NL & LA & NF & RL & FW & DW \\
\hline $\mathrm{PH}$ & 1 & & & & & & & & & & \\
\hline MB & $0.34^{*}$ & 1 & & & & & & & & & \\
\hline ND & $0.55^{* * *}$ & $0.30^{*}$ & 1 & & & & & & & & \\
\hline ID & $0.37^{* *}$ & $0.30^{*}$ & $-0.04 \mathrm{~ns}$ & 1 & & & & & & & \\
\hline SD & $0.48^{* *}$ & $0.32^{*}$ & $0.48^{* *}$ & $0.13 \mathrm{~ns}$ & 1 & & & & & & \\
\hline $\mathrm{NL}$ & $-0.15 \mathrm{~ns}$ & $0.21 \mathrm{~ns}$ & $0.01 \mathrm{~ns}$ & $0.10 \mathrm{~ns}$ & $-0.16 \mathrm{~ns}$ & 1 & & & & & \\
\hline LA & $0.34^{*}$ & $-0.17 \mathrm{~ns}$ & $0.18 \mathrm{~ns}$ & $-0.07 \mathrm{~ns}$ & $0.24 \mathrm{~ns}$ & $-0.37^{*}$ & 1 & & & & \\
\hline $\mathrm{NF}$ & $-0.28 \mathrm{~ns}$ & $0.11 \mathrm{~ns}$ & $-0.34^{*}$ & $0.07 \mathrm{~ns}$ & $-0.23 \mathrm{~ns}$ & $0.80^{* * *}$ & $-0.04^{* *}$ & 1 & & & \\
\hline $\mathrm{RL}$ & $-0.16 \mathrm{~ns}$ & $-0.01 \mathrm{~ns}$ & $-0.30^{*}$ & $-0.06 \mathrm{~ns}$ & $-0.23 \mathrm{~ns}$ & $0.17 \mathrm{~ns}$ & $-0.18 \mathrm{~ns}$ & $0.28^{*}$ & 1 & & \\
\hline FW & $0.48^{* *}$ & $0.37^{* *}$ & $0.43^{* *}$ & $0.05 \mathrm{~ns}$ & $0.26 \mathrm{~ns}$ & -0.04 ns & $0.31^{*}$ & $-0.09^{*}$ & $-0.19 \mathrm{~ns}$ & 1 & \\
\hline DW & $0.47^{* *}$ & 0.41 ** & $0.20 \mathrm{~ns}$ & $0.16 \mathrm{~ns}$ & $0.20 \mathrm{~ns}$ & $0.09 \mathrm{~ns}$ & $0.01 \mathrm{~ns}$ & $0.01 \mathrm{~ns}$ & $-0.13 \mathrm{~ns}$ & $0.87^{* * *}$ & 1 \\
\hline
\end{tabular}

Here, PH, MB, ND, ID, SD, NL, LA, NF, RL, FW and DW indicates; Plant height, Main branch, Number of nodes, Internodes distance, Stem dia, Number of leaves, Leaf area, Number of flowers, Root length, Fresh weight and Dry weight respectively. ${ }^{*} 0.05>\mathrm{p}>0.01,{ }^{* *} 0.01>\mathrm{p}>0.001,{ }^{* * *} \mathrm{p}<0.0001$, ns not significant at $\mathrm{p}>0.05$.

V42 and V10 while the minimum $(0.31,1.01$ and0.06) ppm was observed in accessions V35, V15 and V40 (Table 6). According to the analysis of Pearson's correlation coefficient there was also found positive, negative and non-significant correlation among the mineral compositions (Table 7).

The Pearson's similarity coefficients were employed for clustering the collected 45 clones of purslane with the help of UPGMA method to obtain genetic distances from morphological, physiological and mineral traits. At the tertiary branching, the clones were grouped into five clusters (Figure 2) and the similarity coefficients obtained by morphological marker was ranged between 0.07 and 1.38 .

\section{DISCUSSION}

The analysis of variance of 45 purslane accessions regarding all the morphological traits revealed significant variation among all the accessions and measured characteristics in our study (Table 2) proving distinct morphological diversity among the collected samples from different locations of Western Peninsular Malaysia. This is a desired component for breeders to select better parent from bulk materials to develop improved lines. In our study regarding morphological traits; the highest plant height $(40.8 \mathrm{~cm})$ was double compared to the lowest plant height $(20.06 \mathrm{~cm})$ and the average plant height was $30.42 \mathrm{~cm}$. Plant height of the majority of the accessions were found lower than the average value proving the most variable traits among all other measured morphological attributes which can identify easily through visual observation. Numbers of main branches were also varied significantly and the highest number (4.4) was about three times higher than the lowest number of branches (1.4) and very few accessions possesses lower number of branches over the mean numbers (3.03). The highest number of nodes (31) was about four times higher than the lowest value (8.4) and the average number of nodes was 14.54. The variation among internode distance, stem diameter and leaf area were very narrow but differed significantly. More than ten times variation was found from the highest number of leaves (1019.2) to the lowest numbers (97), while number of flowers were the most highly differed (about sixty times more from highest to the lowest) parameters among all 45 purslane accessions and measured traits. Fresh and dry weight were also high significantly differed from lowest $(40 \mathrm{~g}$ and $2.71 \mathrm{~g}$ ) to the highest ( $280 \mathrm{~g}$ and $29.16 \mathrm{~g}$ ) value which were about seven and 14 times higher from the lowest value respectively (Table 2). The findings of our study regarding some of the parameters were in agreement with the findings of Lokhande et al. (2009) who worked with sea purslane.

The Pearson's correlation coefficient analysis (Table 3) revealed that plant height was highly $(\mathrm{p}<0.0001)$ correlated with main branch, moderately $(\mathrm{p}<0.01)$ correlated with number of nodes, internodes distance, stem diameter, leaf area, fresh and dry weight while non-significant with number of leaves, number of flower and root length. Number of leaves and fresh weight is also very highly $(\mathrm{p}<0.0001)$ correlated with number of flowers and dry weight respectively. On the contrary the internode distance, stem diameter and root length is mostly non-significant with all the interacted parameters.

Plant physiology is directly associated with all types of plant growth and metabolic activities including responses to adverse environments (Nielsen and Jewett, 2007). In our study significant variations were also observed for all the measured physiological traits (Table 4). All thorough the observation accession wise narrow variation was recorded for total chlorophyll contents though there had also nonsignificant results for several accessions. Few accessions (V2, V7, V8, V14, V17, V19, V22, V24, V27, V36 and V40) also produced lower chlorophyll content than the average value (Table 4). Net photosynthesis rate were also varied very narrowly among the accessions but were statistically significant and more than half of the total accessions showed lower photosynthetic rate compared to mean value (Table 4). On the other hand the highest transpiration rate $(2.86$ 
Table 4. Comparison among different physiological traits of purslane accessions

\begin{tabular}{|c|c|c|c|c|c|}
\hline Accessions & Chlorophyll & Photosynthesis & Stomatal cond. & Transpiration & Water Vapor Deficit \\
\hline V1 & 31.22 & 20.8 & 0.02 & 0.46 & 2.65 \\
\hline V2 & 29.52 & 24 & 0.04 & 0.93 & 2.53 \\
\hline V3 & 32.41 & 23.61 & 0.23 & 2.79 & 1.67 \\
\hline V4 & 34.34 & 21.08 & 0.02 & 0.53 & 2.57 \\
\hline V5 & 31.34 & 22.09 & 0.03 & 0.56 & 2.33 \\
\hline V6 & 35.42 & 24.11 & 0.05 & 1.03 & 2.05 \\
\hline V7 & 26.2 & 24.05 & 0.11 & 1.07 & 0.96 \\
\hline V8 & 28.56 & 24.29 & 0.12 & 1.03 & 0.87 \\
\hline V9 & 35.94 & 23 & 0.17 & 2.86 & 1.72 \\
\hline V10 & 37.2 & 24.38 & 0.28 & 2.86 & 1.73 \\
\hline V11 & 33.92 & 25.58 & 0.06 & 1.09 & 1.83 \\
\hline V12 & 31.6 & 25.7 & 0.06 & 1.16 & 1.96 \\
\hline V13 & 32.72 & 27.7 & 0.2 & 1.26 & 1.98 \\
\hline V14 & 27.47 & 25.28 & 0.02 & 0.65 & 2.58 \\
\hline V15 & 35.42 & 25.11 & 0.05 & 1.06 & 2.23 \\
\hline V16 & 33.12 & 26.07 & 0.05 & 1.11 & 1.47 \\
\hline V17 & 27.14 & 24.34 & 0.03 & 1.07 & 2.19 \\
\hline V18 & 32.18 & 24.14 & 0.05 & 1.5 & 2.26 \\
\hline V19 & 26.2 & 28.18 & 0.05 & 1.15 & 1.9 \\
\hline V20 & 33.29 & 25.23 & 0.05 & 1.23 & 2.18 \\
\hline V21 & 33.94 & 27.45 & 0.14 & 2.11 & 1.7 \\
\hline V22 & 28.56 & 22.23 & 0.08 & 1.69 & 1.14 \\
\hline V23 & 33.6 & 22.95 & 0.09 & 2.35 & 2.12 \\
\hline V24 & 26.2 & 25.45 & 0.05 & 1.5 & 2.27 \\
\hline V25 & 37.16 & 26.5 & 0.14 & 1.12 & 2.14 \\
\hline V26 & 31.6 & 25.36 & 0.03 & 0.62 & 2.11 \\
\hline V27 & 29.12 & 27.58 & 0.08 & 1.75 & 2.17 \\
\hline V28 & 32.14 & 23.45 & 0.04 & 0.96 & 2.21 \\
\hline V29 & 39.52 & 22.83 & 0.03 & 0.68 & 2.2 \\
\hline V30 & 31.91 & 26.43 & 0.06 & 1.31 & 2.13 \\
\hline V31 & 38.65 & 24.33 & 0.15 & 0.73 & 0.51 \\
\hline V32 & 33.46 & 21.18 & 0.05 & 0.68 & 1.19 \\
\hline V33 & 35.7 & 25.65 & 0.08 & 0.54 & 0.7 \\
\hline V34 & 38.33 & 21.13 & 0.1 & 0.83 & 0.84 \\
\hline V35 & 32.92 & 23.88 & 0.11 & 0.98 & 0.88 \\
\hline V36 & 27.84 & 23.35 & 0.03 & 0.62 & 2.15 \\
\hline V37 & 33.86 & 23.3 & 0.03 & 0.53 & 2.17 \\
\hline V38 & 35.4 & 25.03 & 0.04 & 0.79 & 2.12 \\
\hline V39 & 35.5 & 24.23 & 0.04 & 0.79 & 2.12 \\
\hline V40 & 27.38 & 24.27 & 0.03 & 0.76 & 2.11 \\
\hline V41 & 35.82 & 21.1 & 0.03 & 0.49 & 1.47 \\
\hline V42 & 35.06 & 24.35 & 0.06 & 0.89 & 1.5 \\
\hline V43 & 36.96 & 22.58 & 0.12 & 1.83 & 1.5 \\
\hline V44 & 32.86 & 28.73 & 0.12 & 2.06 & 1.77 \\
\hline V45 & 31.78 & 21.64 & 0.03 & 0.63 & 2.15 \\
\hline Mean & 32.67 & 24.3 & 0.07 & 1.16 & 1.84 \\
\hline Max. & 39.52 & 28.73 & 0.28 & 2.86 & 2.65 \\
\hline Min & 26.2 & 20.8 & 0.02 & 0.46 & 0.51 \\
\hline LSD & 1.83 & 0.8 & 0.03 & 0.14 & 0.28 \\
\hline $\mathrm{CV}$ & 3.47 & 2.03 & 25.12 & 7.62 & 9.6 \\
\hline
\end{tabular}

Table 5. Pearson's correlation coefficient among different physiological traits of purslane

\begin{tabular}{|c|c|c|c|c|c|}
\hline Factor & Chlorophyll & Photosynthesis & Stomatal cond. & Transpiration & Water Vap. Def \\
\hline Chlorophyll & 1 & & & & \\
\hline Photosynthesis & -0.19 ns & 1 & & & \\
\hline Stomatal cond. & $0.28^{*}$ & $0.22^{\text {ns }}$ & 1 & & \\
\hline Transpiration & 0.06 ns & 0.26 ns & $0.73^{* * *}$ & 1 & \\
\hline Water Vap. Def & $-0.22^{\mathrm{ns}}$ & $0.05^{\text {ns }}$ & $-0.42 * *$ & -0.07 ns & 1 \\
\hline
\end{tabular}

Here, ${ }^{*} 0.05>\mathrm{p}>0.01,{ }^{* *} 0.01>\mathrm{p}>0.001,{ }^{* * *} \mathrm{p}<0.0001$, ns not significant at $\mathrm{p}>0.05$. 
$\mathrm{mol} / \mathrm{m}^{2} / \mathrm{sec}$ ) was more than six times higher compared to the lowest rate $\left(0.46 \mathrm{~mol} / \mathrm{m}^{2} / \mathrm{sec}\right)$ with the average value of $1.16 \mathrm{~mol} / \mathrm{m}^{2} / \mathrm{sec}$ (Table 4). The variation for stomatal conductance and water vapor deficit were also significant and but differed narrowly among accessions (Table 4).
From the Pearson's correlation coefficient analysis (Table 5) it is seen that stomatal conductance is very highly correlated with Transpiration then significant but negatively correlated with water vapor deficit. Total chlorophyll content is significant $(\mathrm{p}<0.05)$ with stomatal conductance but non-

Table 6. Micro and macro mineral compositions of 45 collected purslane accessions (ppm)

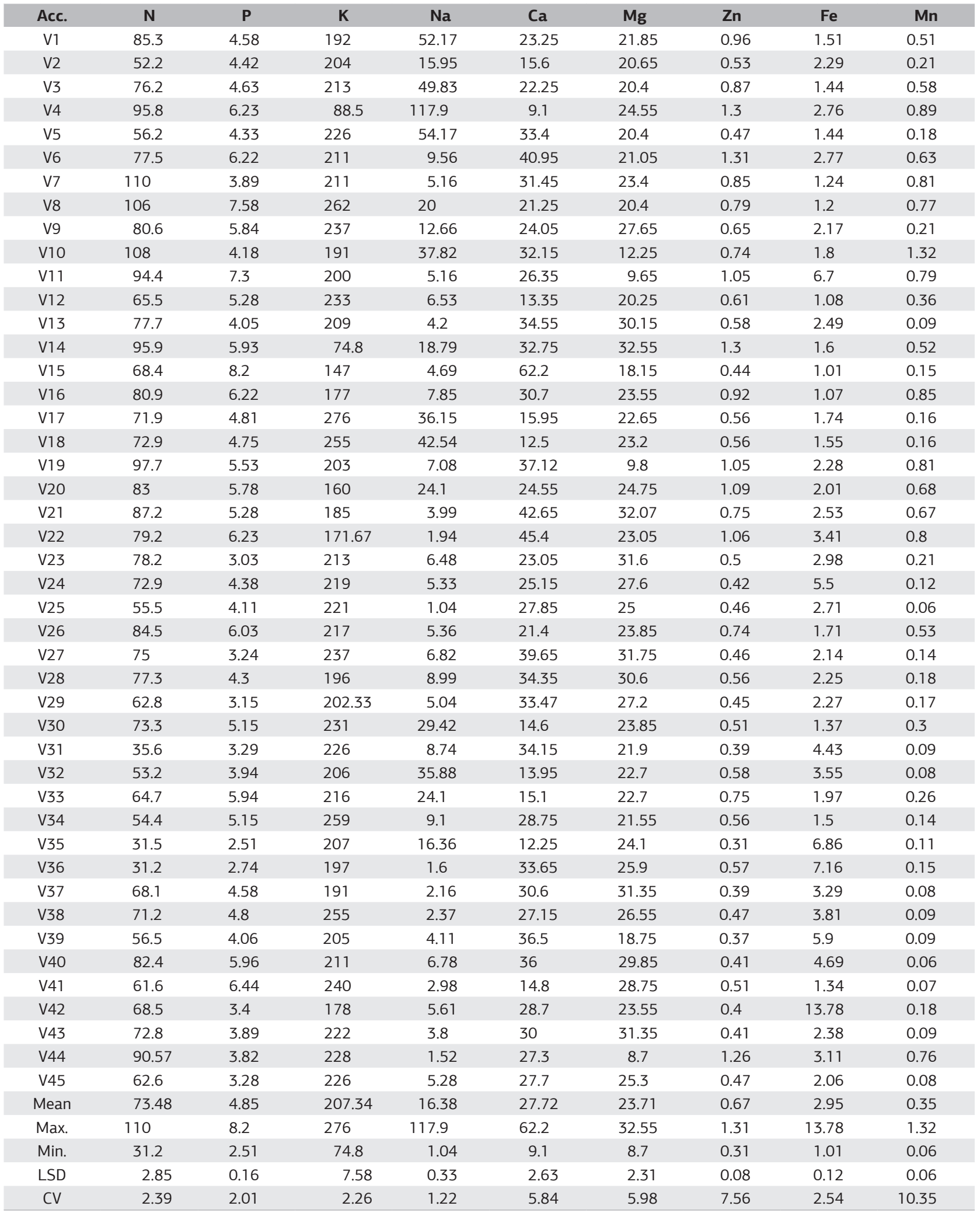


Table 7. Pearson's correlation coefficient among different mineral nutrients of purslane

\begin{tabular}{|c|c|c|c|c|c|c|c|c|c|}
\hline Factor & $\mathbf{N}$ & $\mathbf{P}$ & K & $\mathrm{Na}$ & $\mathrm{Ca}$ & $\mathrm{Mg}$ & $\mathrm{Zn}$ & $\mathrm{Fe}$ & Mn \\
\hline $\mathrm{N}$ & 1 & & & & & & & & \\
\hline$P$ & $0.46^{* *}$ & 1 & & & & & & & \\
\hline K & $-0.24 \mathrm{~ns}$ & $-0.21 \mathrm{~ns}$ & 1 & & & & & & \\
\hline $\mathrm{Na}$ & $0.17 \mathrm{~ns}$ & $0.11 \mathrm{~ns}$ & $-0.29^{*}$ & 1 & & & & & \\
\hline $\mathrm{Ca}$ & $0.10 \mathrm{~ns}$ & $0.12 \mathrm{~ns}$ & $-0.24 \mathrm{~ns}$ & $-0.45^{* *}$ & 1 & & & & \\
\hline $\mathrm{Mg}$ & $-0.17 \mathrm{~ns}$ & $-0.22 \mathrm{~ns}$ & -0.09 ns & $-0.12 \mathrm{~ns}$ & 0.01 ns & 1 & & & \\
\hline $\mathrm{Zn}$ & $0.62^{* * *}$ & $0.45^{* *}$ & $-0.47^{* *}$ & $0.31^{*}$ & $0.01 \mathrm{~ns}$ & $-0.35^{*}$ & 1 & & \\
\hline $\mathrm{Fe}$ & $-0.31^{*}$ & $-0.33^{*}$ & $-0.11 \mathrm{~ns}$ & $-0.21 \mathrm{~ns}$ & 0.04 ns & $-0.03 \mathrm{~ns}$ & $-0.23 \mathrm{~ns}$ & 1 & \\
\hline $\mathrm{Mn}$ & $0.74^{* * *}$ & $0.35^{*}$ & $-0.33^{*}$ & $0.28 \mathrm{~ns}$ & $0.04 \mathrm{~ns}$ & $-0.47^{* *}$ & $0.78^{* * *}$ & $0.19 \mathrm{~ns}$ & 1 \\
\hline
\end{tabular}

Here $\mathrm{N}, \mathrm{P}, \mathrm{K}, \mathrm{Na}, \mathrm{Ca}, \mathrm{Mg}, \mathrm{Zn}, \mathrm{Fe}$ and $\mathrm{Mn}$ indicates Nitrogen, Phosphorus, Potassium, Sodium, Calcium, Magnesium, Zinc, Iron and Manganese respectively. ${ }^{*} 0.05>\mathrm{p}>0.01$, ${ }^{* *} 0.01>\mathrm{p}>0.001,{ }^{* * *} \mathrm{p}<0.0001$, ns not significant at $\mathrm{p}>0.05$.

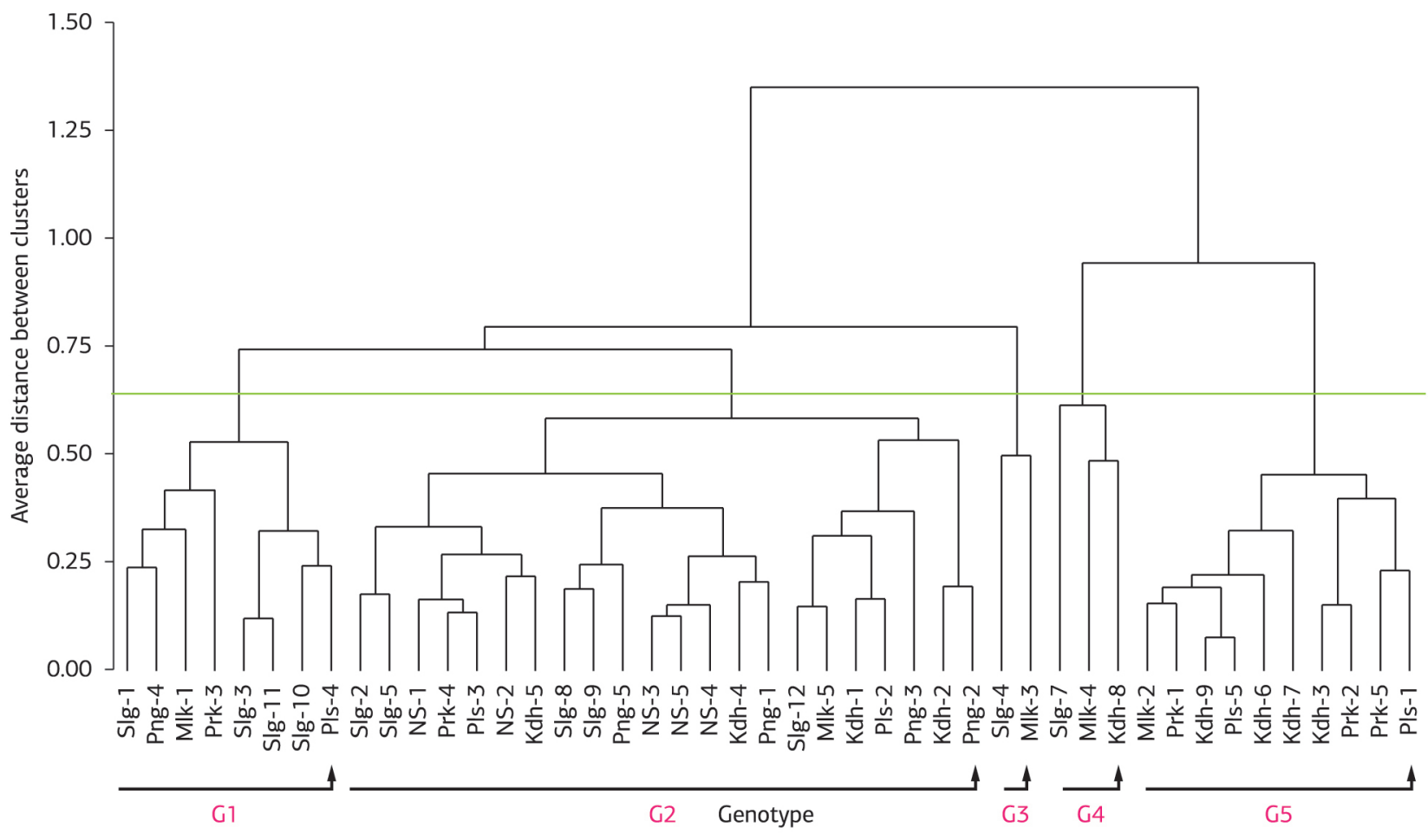

Figure 2. Dendrogram showing phenotypic relationship among the collected 45 accessions of purslane based on Pearson's similarity coefficient generated by morphological, physiological and mineral markers. Slg: Selangor, NS: Nigeri Sembilan, Prk: Perak, Png: Penang, Pls: Perlis, Kdh: Kedah, Mlk: Melaka.

significant with net photosynthesis, transpiration and water vapor deficit. While the net photosynthesis rate is mostly non-significant with stomatal conductance, transpiration and water vapor deficit.

From the macro and micro mineral composition analysis results it is found that Potassium $(\mathrm{K})$ was the highest amount among all other minerals followed by Nitrogen $(\mathrm{N})$, Calcium $(\mathrm{Ca})$, Magnesium (Mg), Sodium (Na), Phosphorus (P), Iron $(\mathrm{Fe})$ and Manganese (Mn) respectively. Bangash et al. (2011), Hussain et al. (2011), Mohamed and Hussein (1994) also reported their findings about the highest amount of Potassium (P) but got different results regarding other minerals.

According to the Pearson's correlation coefficient among different mineral nutrients of purslane it was observed that,
Nitrogen $(\mathrm{N})$ was very highly correlated with Zinc $(\mathrm{Zn})$, Manganese (Mn) and Phosphorus (P) but non-significantly correlated with Sodium $(\mathrm{Na})$ and Calcium $(\mathrm{Ca})$ while Phosphorus (P) significantly correlated with $\mathrm{Zn}, \mathrm{Fe}$ and $\mathrm{Mn}$ but non-significantly correlated with $\mathrm{K}, \mathrm{Na}, \mathrm{Ca}$ and $\mathrm{Mg}$. Calcium $(\mathrm{Ca})$ is mostly non-significant with $\mathrm{Mg}, \mathrm{Zn}, \mathrm{Fe}$ and $\mathrm{Mn}$ where $\mathrm{Zn}$ is very significant with $\mathrm{N}, \mathrm{P}, \mathrm{K}, \mathrm{Na}$ and $\mathrm{Mg}$ but only non-significant with $\mathrm{Ca}$. This finding is partially supported with the results described by Uddin et al. (2012).

Based on the Pearson's similarity coefficients analysis with the help of UPGMA method at the tertiary branching, the clones were grouped into five clusters (Figure 2). The first group (G1) included the clones Slg-1, Slg-3, Slg-10, Slg-11, Mlk-1, Prk-3, Png-4 and Pls-4; the second group 
(G2) included Slg,-2, Slg-5, Slg-8, Slg-9, Slg-12, NS-1, NS-2, NS-3, NS-4, NS-5, Prk-4, Pls-2, Pls-3, Prk-4, Kdh1, Kdh-2, Kdh-4, Kdh-5, Png-1, Png-2, Png-3 and Png-5; while, the third group (G3) consisted of clones Mlk-3 and Slg-4. The fourth cluster (G4) included the clones Slg-7, Mlk- 4 and Kdh- 8 and finally the fifth group (G5) included Mlk-2, Prk-2, Prk-3, Kdh-3, Kdh-6, Kdh-7, Kdh-9, Pls-1 and Pls-5. The Pearson's similarity coefficient obtained by morpho-physiological and nutritional marker was ranged between 0.07 and 1.38. The highest pair wise phenotypic similarity was observed for the clones Kdh-9 and Pls-5 (0.07). Lokhande et al. (2009) has described the UPGMA dendrogram for morphological traits of collected Seapurslane (Sesuvium portulacastrum L.) clones.

\section{CONCLUSION}

The diversity analysis in most of the plant species is primarily based on morphological traits evaluation which is related with the genetic and environmental factors. Purslane morphological diversity indicating the variation might be due to adverse anthropogenic force along with the changeable natural circumstances. Additional, a range of clones from the different eco-geographic localities might have originated from local places of wild profusion or vice versa. The morpho-pysiological variation among the clones is very important to select the better parent for future breeding purpose. Purslane is a plant with good nutritional potential especially contain very high amount of essential minerals. The nutritional characterization of purslane is also very helpful for breeders and consumers for improved variety development, easy cultivation as well as commercialization for safe and easy source of plants essential nutrient for safeguarding of sound life and usual body performance.

\section{ACKNOWLEDGEMENTS}

The authors sincerely acknowledge UPM Research University Grant (01-02-12-1695RU) for financial support of the project and IGRF (International Graduate Research Fellowship, UPM) for PhD Fellowship.

\section{REFERENCES}

ALAM, M.A.; JURAIMI, A.S.; RAFII, M.Y; HAMID, A.A.; UDDIN, M.K.; ALAM, M.Z.; LATIF, M.A. Genetic improvement of Purslane (Portulaca oleracea L.) and its future prospects. Molecular Biology Reports, 2014a. No prelo. http://dx.doi.org/10.1007/ s11033-014-3628-1

ALAM, M.A.; JURAIMI, A.S.; RAFII, M.Y.; HAMID, A.A.; ASLANI, F.; HASAN, M.M.; ZAINUDIN, M.A.M.; UDDIN,
M.K. Evaluation of antioxidant compounds, antioxidant activities and mineral composition of 13 collected purslane (Portulaca oleracea L.) accessions. BioMed Research International, v.2014, p.1-10, 2014b. PMid:24579078 PMCid:PMC3918865. http://dx.doi. org/10.1155/2014/296063

ALAM, M.A.; JURAIMI, A.S.; RAFII, M.Y.; HAMID, A.A.; ASLANI, F.; ALAM, M.Z. Effects of salinity on phenolic compounds and antioxidant activities of 13 collected purslane (Portulaca oleracea L.) germplasms. Food Chemistry, v. 169, p. 439-447, $2014 \mathrm{c}$.

ALAM, M.A.; JURAIMI, A.S.; RAFII, M.Y.; HAMID, A.A.; ASLANI, F. Screening of Purslane (Portulaca oleracea L.) accessions for high salt tolerance. Scientific World Journal, v.2014, p.1-12. 2014d.

BALYAN, R.S.; BHAN, V.M. Emergence, growth, and reproduction of horse purslane (Trianthema portulacastrum) as influenced by environmental conditions. Weed Science, v.34, p.516-519, 1986.

BANGASH, J.A.; ARIF, M.; KHAN, F.; AMIN-UR-RAHMAN, F.K.; HISSAINI, I. Proximate Composition, Minerals and Vitamins Content of Selected Vegetables Grown in Peshawar. Journal- Chemical Society of Pakistan, v.33, p.118-112, 2011.

BILJANA, B.; ACA, M. Correlation between Nitrogen and Chlorophyll Content in Wheat (Triticum aestivum L.). Kragujevac Journal of Science, v.31, p.69-74, 2009.

GALINATO, M.I.; MOODY, K.; PIGGIN, C.M. Upland rice weeds of South and Southeast Asia.Makati City, Philippines. International Rice Research Institute, 1999. 156p.

GRIEVE, C.M.; SUAREZ, D.L. Purslane (Portulaca oleracea L.): a halophytic crop for drainage water reuse systems. Plant Soil, v.192, p.277-283, 1997. http://dx.doi.org/10.1023/A:1004276804529

HAWK, P.B.; OSER, B.L.; SUMMERSON, W.H. Practical physiological chemistry. USA: The Blockiston Co., 1948.

HELEN, S.; How Contributor. How to Imbibe Purslane Seeds. Disponível em: <http://www.ehow.com/how_7999696_imbibepurslane-seeds.html. 2014>. Acesso: 4 set. 2014

HUSSAIN, J.; REHMAN, N.R.; KHAN, A.L.; HUSSAIN, H.; AlHARRASI, A.; ALI, L.; SAMI, F.; SHINWARI, Z.K. Determination of macro and micronutrients and nutritional prospects of six vegetable species of Mardan, Pakistan. Pakistan Journal of Botany, v.43, p.2829-2833, 2011.

JONAS, V.; DUNN, S.; SATCEWICZ, M. Life History as Related to Weed Control in the Northwest: 7 species of Purslane. Research Bulletin 598, Northwest Regional Publication, Amherst, USA: The University of Massachusetts, 1972.

LIU, L.; PETER, H.; YE-FANG, Z.; ZHI-QIANG, X.; CHARLES, H.; REN, Z. Fatty acids and b-carotene in Australian Purslane (Portulaca oleracea) varieties. Journal of Chromatography A, v.893, p.207-213, 2000. http://dx.doi.org/10.1016/S0021-9673(00)00747-0

LOKHANDE, V.H.; NIKAM, T.D.; PATADE, V.Y.; SURASANNA, P. Morphological and molecular diversity analysis among the Indian clones of Sesuvium portulacastrum L. Genetic Resources and Crop Evolution, v.56, p.705-717. 2009. http://dx.doi.org/10.1007/ s10722-008-9396-9

MA, T.; ZUAZAGA, G. Micro-Kjeldahl determination of nitrogen. A new indicator and an improved rapid method. Industrial Engineering 
Chemistry Analytical Edition, v.14, p.280-282, 1942. http://dx.doi. org/10.1021/i560103a035

MOHAMED, A.I.; HUSSEIN, A.S. Chemical composition of purslane (Portulaca oleracea). Plant Foods for Human Nutrition, v.45, p.1-9. 1994. PMid:8146099. http://dx.doi.org/10.1007/BF01091224

NIELSEN, J.; JEWETT, M.C. The importance of anatomy and physiology in plant metabolomics. Topics in Current Genetics, v.18, p.254-278, 2007.

RASHED, A.N.; AFIFI, F.U.; DISI, A.M. Simple evaluation of the wound healing activity of a crude extract of Portulaca oleracea L. (growing in Jordan) in Musmusculus JVI- 1. Journal of Ethnopharmacology, v.88, p.131-136, 2003. http://dx.doi.org/10.1016/S0378-8741(03)00194-6

SAMY, J.; SUGUMARAN, M.; LEE, K.L.W. Herbs of Malaysia: An Introduction to the medicinal, culinary, aromatic and cosmetic use of herbs. Kuala Lumpur: Times Edition, 2004.

SAS INSTITUTE. SAS system for Windows. Version 9.3 (TS1M2) Cary: SAS Institute. 2013.

SIMOPOULOS, A.P.; NORMAN, H.A.; GILLASPY, J.E. Purslane in human nutrition and its potential for world agriculture. World Review of Nutrition and Dietetics, v.77, p.47-74, 1995. PMid:7732700
SIMOPOULOS, A.P.; NORMAN, H.A.; GILLASPY, J.E.; DUKE, J.A. Common purslane: A source of Omega-3 fatty acids and antioxidants. Journal of the American College of Nutrition, v.11, p.374-382, 1992. PMid:1354675. http://dx.doi.org/10.1080/073 15724.1992 .10718240

UDDIN, M.K.; JURAIMI, A.S.; ANWAR, F.; HOSSAIN, M.A.; ALAM, M.A. Effect of salinity on proximate mineral composition of purslane (Portulca oleracea L.). Australian Journal of Crop Science, v.6, p.1732-1736, 2012.

YAZICI, I.; TURKAN, I.; HEDIYE, A.; SEKMEN, T.D. Salinity tolerance of purslane (Portulaca oleracea L.) is achieved by enhanced antioxidative system, lower level of lipid peroxidation and proline accumulation. Environmental and Expimental Botany, v.61, p.49-57, 2007. http://dx.doi.org/10.1016/j.envexpbot.2007.02.010

YOSHIDA, S.; FORNO, D.; COOK J.B.; GOMEZ, K.A. Laboratory manual for physiological studies of Rice. In: SEKINE, T.; SASAKAWA, T.; MORITA, S.; KIMURA, T.; KURATOM, K. Routine procedure for growing rice plants in culture solution. Manila: The International Rice Research Institute, 1965. 